DOI 10.15393/j9.art.2018.5321

УДК 821.161.1.09“18”

Вячеслав Анатольевич Кошелев

(Арзамас, Российская Федерачия)

viacheslav.koshelev@mail.ru

\title{
Об одном давнем «парадоксе»: Жанр маргина дий А. С. Пушкина на «Опытах в стихах и прозе» К. Н. Батюшкова
}

Аннотация. В центре статьи - известные русские литературные маргиналии: заметки А. С. Пушкина на полях поэтического тома «Опытов в стихах и прозе» К. Н. Батюшкова и научная полемика, им посвященная. Автор предлагает серию аргументов в доказательство того, что пушкинские пометы имели не полемический, а редакторский характер. Они были вызваны соответствующей просьбой самого Батюшкова, высказанной в 1818 г., и являются попыткой «младшего» поэта выполнить «критическое задание» своего предшественника. Пометы свидетельствуют об упорном и многократном обращении Пушкина к книге Батюшкова. Эта «многократность» и создала проблему датировки помет: разные исследователи, каждый по-своему интерпретируя пушкинские высказывания, относят их то к концу 1810-х, то к 1820-м, то к середине 1830 -х гг. Автор доказывает необходимость рассматривать прежде всего целевую установку помет и их историю: в свете двусторонней «прагматики» проблема датировки помет уходит на второй план.

Ключевые слова: К. Н. Батюшков, «Опыты в стихах и прозе», А. С. Пушкин, пометы на полях, жанр маргиналий, редактор, критика, полемика, датировка, интерпретация

$\mathrm{Y}$

же второе столетие длится полемика, посвященная самым известным русским литературным маргиналиям XIX столетия - пометам А. С. Пушкина на полях «Опытов в стихах» К. Н. Батюшкова. По традиции она начинается описанием утраченного источника.

\section{Источник}

Б. Л. Модзалевский в предисловии к знаменитому библиографическому описанию библиотеки А. С. Пушкина (с приобретения которой и начался Пушкинский Дом) сообщил, что «первый шаг» был сделан академиком Л. Н. Майковым в начале 1890-х гг.: «Получив от А. А. Пушкина принадлежавший 
его отцу экземпляр “Опытов” Батюшкова (изд. 1817 г.) и вполне правильно оценив значение сделанных поэтом на полях книги критических замечаний, Леонид Николаевич начал переговоры с потомками Пушкина о предоставлении ему возможности ознакомиться со всею библиотекою поэта» [Модзалевский: 10].

При этом показательно, что даже и после того, как вся библиотека Пушкина (более трех с половиной тысяч книг) была продана Академии Наук, А. А. Пушкин, по каким-то соображениям, оставил именно экземпляр «Опытов...» Батюшкова «с замечаниями Пушкина» в своем личном пользовании [Модзалевский: 13]. В сущности, это была не самая ценная книга из библиотеки: переплетенный экземпляр двухтомного издания 1817 г., вторая (стихотворная) часть которого «оказалась испещрена многочисленными (около двух сотен) пушкинскими пометами, краткими и пространными, выполненными чернилами и карандашом» [Проскурин, 2003: 252]. Именно «маргиналии» составляли основную ценность этой книги и обусловили столь трепетное отношение к ней сына и внука поэта.

Вероятно, А. А. Пушкин разрешил академику Майкову пользоваться книгой недолгое, ограниченное время - и тот «скопировал в свой экземпляр “Опытов” пушкинские заметки в их подлинном размещении, последовательности и написании» [Комарович: 885]. Считается, что эта копия была сделана «почти с дипломатической точностью» [Балакин: 10] - но проверить степень этой «точности» невозможно: подлинный пушкинский экземпляр пропал, и копия Майкова (РО ИРЛИ. Ф. 244. Оп. 6. № 38) оказалась единственным источником для последующего восстановления текста этих помет.

Единственным из ученых, кто видел подлинник, был Л. Н. Майков. Но в его задачу не входило комплексное исследование пушкинских маргиналий. Он представил лишь избранные пометы, сопроводив их собственной интерпретацией. Его статья «Пушкин о Батюшкове» (впервые напечатанная в 1894 г. [Майков: 528-555]) стала основой для публикации «избранных» помет в собрании сочинений Пушкина под редакцией С. А. Венгерова [Пушкин, 1910: 490-500] ${ }^{1}$. В ней 
«Майков не ставил своей целью точную публикацию пушкинских помет, в их последовательности и в соотнесенности с поэтическим текстом, их вызвавшим. Он использовал их как первоклассный материал в исследовании избранной темы, а вопрос датировки решал лишь попутно, не стремясь исчерпать все аргументы pro и contra» [Сандомирская: 17-18].

Научную публикацию помет подготовил (по «майковской» копии) В. Л. Комарович, посвятивший им большую статью в «Литературном наследстве». 12-й том Большого Академического издания Пушкина вышел в свет лишь в 1949 г. (уже после смерти ученого) - и с этого времени пометы цитируются именно по этому тексту [Пушкин, 1949: 257-284].

\section{Проблема датировки}

Еще полвека назад Р. М. Горохова, указав на то, что значение пушкинских помет неоценимо «для понимания целого ряда вопросов, связанных с эстетическими воззрениями Пушкина и его творчеством», посетовала на то, что в этих двух сотнях разнородных маргиналий «не все ясно, начиная с их датировки и кончая толкованием отдельных замечаний». На основе одних и тех же высказываний разные исследователи приходили «к самым разным выводам и заставляли относить пометы то к 1817 г., то к 1820-м годам (1820-1824 или 1826-1828), датировать их “не ранее 1830 г.” или даже “после 1834 г.”” [Горохова: 24].

Поскольку искомую «датировку» приходилось определять, опираясь на «косвенные» данные (связанные прежде всего с содержанием помет), то каждый из исследователей исходил из собственных истолкований отдельных замечаний, отыскивая им то или иное соответствие в творческой биографии Пушкина.

Так, Л. Н. Майков указал, что «во всяком случае, приурочивать эти заметки можно только к середине двадцатых годов, когда дарование Пушкина окончательно созрело и вышло на свою настоящую дорогу». В качестве основного доказательства он привел то обстоятельство, что в пушкинском экземпляре «Опытов...» «на белом листе, находящемся перед заднею доскою переплета», вписано стихотворение Батюшкова «Есть 
наслаждение и в дикости лесов...», в книгу не вошедшее и напечатанное «только в 1828 году в “Северных Цветах"». Пушкин мог узнать это стихотворение лишь «по своем приезде в Москву из деревенской ссылки». Следовательно, «замечания, находящиеся в рассмотренном нами экземпляре “Опытов” Батюшкова, сделаны Пушкиным не ранее второй половины 1826 года u, может бьmь, не позже 1828 года, когда вышеупомянутая пиеса Батюшкова появилась в печати». Эта датировка подкреплялась еще и рядом «мелких обстоятельств» (курсив мой. - В. К.) [Майков: 289-291].

В. Л. Комарович, тщательно изучивший пометы, предположил, что они заносились в книгу в два приема. Он обратил внимание на палеографическую особенность: подавляющее число помет карандашные; чернилами же вписаны только пять помет (в основном - комплементарных) к стихотворениям, впервые напечатанным в «Опытах...» и воспринятых Пушкиным как стихотворные «новинки» («Странствователь и Домосед», «Переход через Реин», «Умирающий Тасс», «Беседка Муз»). По мнению исследователя, «чернильные» пометы могут быть датированы 1817 2. и сделаны непосредственно после выхода «Опытов...» [Комарович: 886-890]. Основные же пометы (карандашом) сделаны не ранее 1830 г. - главный аргумент связан с замечанием Пушкина по поводу элегии «Умирающий Тасс»: «Это умирающий В<асилий $>$ Л<ьвович>, - а не Торквато». «Психологически едва ли допустимо, чтоб Пушкин стал сравнивать героя Батюшкова c “умирающим Василием Львовичем” до того, как последний действительно умер...»- отметил ученый, предложив серию свидетельств об обстоятельствах смерти (20 августа 1830 г.) «Нестора Арзамаса», восхитившей Пушкина. По предположению Комаровича, скорее всего пометы делались осенью 18302. в Болдино, куда Пушкин уехал сразу после похорон дяди [Комарович: 894-895]. К этой датировке присоединились многие ученые (см.: [Лотман], [Семенко: 491-492]).

В 1974 г. В. Б. Сандомирская решительно оспорила эту точку зрения. Она предприняла попытку поставить пометы в общий контекст творческих отношений Пушкина с Батюшкову и обнаружила «ряд соответствий между произведениями Батюшкова и творческими замыслами Пушкина» именно 
в 1821-1824 22. Этим временем исследователь и предложила датировать пушкинские пометы [Сандомирская: 35]. Что же касается фразы об «умирающем Василии Львовиче», то в ней, пишет ученый, «важно не то, что он “умирающий”, а то, что он “Василий Львович”, т. е. определенный тип характера, противоположный Тассо». Пушкин делает акцент на том, что герой элегии похож на добродушного арзамасского старосту, а не на величественного певца: это ироническое упоминание дяди психологически скорее возможно до его смерти, чем после нее (см.: [Сандомирская: 20-23]; ср.: [Горохова: 28-30]).

И. М. Семенко в статье, сопровождающей подготовленное ею издание «Опытов в стихах и прозе» в серии «Литературные памятники» (1977), предложила новую гипотезу о времени возникновения помет. Обнаружив, что одна из помет перекликается с дневниковой записью В. К. Кюхельбекера от 28 апреля 1834 г., она предположила, что пушкинская помета является репликой в споре поэта со своим лицейским приятелем, который состоял в переписке с Пушкиным и пересылал ему свои рукописи, а возможно, и части дневника. Поэтому «пушкинские заметки могли быть сделаны после 1834 2.» (курсив мой. - В. К.) [Семенко: 491].

Тогда же Р. М. Горохова обнаружила перекличку одной из помет со статьей П. А. Плетнева «Разбор элегии Батюшкова "Умирающий Тасс"», опубликованной во второй половине 1823 г. Пушкин скорее всего мог прочитать эту статью уже в Михайловском - тогда, «когда готовил к печати собственный сборник: в конце 1824 - начале 1825 г.» (курсив мой. - В. К.) [Горохова: 32-33]. Именно «на грани 1824-1825 гг.» в Михайловском Пушкин, с карандашом в руках, и читал «Опыты...» Батюшкова.

В предложенной нами в 1995 г. гипотезе, изложенной в работе «В предчувствии Пушкина: К. Н. Батюшков в русской словесности начала XIX века», отличающейся, по мнению О. А. Проскурина, «как оригинальностью, так и парадоксальностью» [Проскурин, 2003: 260], сама по себе проблема «датировки» кажется второстепенной. В этой работе мы исходили из того, что Пушкин делал на экземпляре «Опытов...» заметки не «для себя», а с точной целевой установкой. Большая часть помет сделана молодым Пушкиным для самого Батюшкова, 
по его просьбе, перед его отъездом в ноябре 1818 г. из Петербурга в Неаполь. Другая же часть могла быть сделана в 18221826 г2., когда Пушкин, услышав о помешательстве Батюшкова и остро переживая эту потерю «первоклассного поэта» для литературы, перечитывал его стихи [Кошелев, 1995].

О. А. Проскурин, согласившись с признанием важности ответа на вопрос, зачем и для кого Пушкин делал свои пометы на полях чужой книги, представил их не «редакторскими», а «полемическими» пометами: они явились «репликами и аргументами» в одесских спорах о Батюшкове с ведущими поэтами-«батюшковианцами» - С. Е. Раичем и В. И. Туманским. «Скорее всего, пометы были результатом уже имевших место споров и выступали аргументами для их продолжения. Несомненно при этом, что обобщающие, оценочные комментарии под текстами предназначались не “для себя”, а для чтения посторонним глазом - на это указывают коммуникативная модальность некоторых из них <...>. Разница между записями карандашом и чернилами свидетельствует о том, что записи делались не в один прием. Но никаких эстетических оснований относить комментарии к разным периодам творческого пути Пушкина <...> у нас нет: вероятная дистанция между ними - не годы, а дни или даже минуты» [Проскурин, 2003: 265-266]. Соотнеся свою гипотезу с фактами «одесской» биографии Пушкина, исследователь датировал пометы августом - первой половиной сентября 1823 г.

Приведя эту вереницу предложенных датировок, А. Ю. Балакин указал, что все исследователи смотрели на пушкинские пометы «как на “собранье пестрых глав”, слабо связанных друг с другом смыслом и логикой». И предложил взглянуть на них «как на единый палеографический комплекс»: «Те их фрагменты, которые мешали той или иной концепции, либо не комментировались, либо объявлялись случайными и несущественными. Нам же хочется попытаться показать, что они все взаимосвязаны, подчинены единой логике, делались в одно время и с одной целью» [Балакин: 13].

Исходя из этого, ученый высказал предположение, что пометы Пушкина связаны с работой нам новым изданием сочинений Батюшкова, которое готовил (по инициативе С. С. Уварова) 
П. А. Плетнев. Плетнев-де «обратился к Пушкину с просьбой помочь ему в этой работе, высказать свои суждения о составе будущего сборника, отметить неудачные стихи и сократить длинноты». Пушкин активно отреагировал на эту просьбу: «Тут мы видим и правку заведомо неудачных, по мнению поэта, мест, и мотивированные рекомендации по редактуре или исключению того или иного стихотворения, и историко-литературные заметки, которые Пушкин делал скорее всего потому, что видел в Плетневе будущего биографа Батюшкова и хотел снабдить его материалом». «Это предположение, заявляет исследователь, - позволяет <...> наиболее удовлетворительно объяснить смысл появления всех без исключения помет, которые нанес на свой экземпляр Пушкин» (курсив мой. - В. К.) [Балакин: 23-24].

Второе издание сочинений Батюшкова («Сочинения в прозе и стихах») имеет цензурное разрешение 19 октября 1833 г. следовательно, пушкинские пометы можно датировать не позднее этого времени. Таков вывод из рассуждений Балакина.

\section{Специфика пушкинских маргинадий}

Выяснение прагматики и целевой направленности помет Пушкина на «Опытах...» Батюшкова чрезвычайно затруднено их смысловой пестротой и разнонаправленностью.

«Замечания, - указала И. М. Семенко, - почти поровну делятся на отрицательные (“вяло”, “плохо”, “черт знает что такое”) и восторженные (“прекрасно", "прелесть", "совершенство", “гармония"). Пушкин выступает как нелицеприятный рецензент, озабоченный при этом интересами автора; более того, он правит местами текст, зачеркивает длинноты, куски текста, которые считает "вялыми". Происходит как бы повторная подготовка текста "Опытов" к печати. Но это, конечно, впечатление кажущееся. Пушкин делал свои замечания для себя. По поводу стихотворения “Мечта", которое он считает не удавшимся, Пушкин пишет то самое словечко “дрянь”, которое так часто встречалось в письмах Батюшкова, умолявшего выкидывать неудавшиеся стихотворения. Пушкин в сущности проделал именно тот отбор, о котором Батюшков просил Гнедича, Вяземского, Жуковского. Нельзя исключить 
того, что одним из поводов для Пушкина взяться за это, по существу, редактирование “Опытов в стихах" было чтение указанных выше писем Батюшкова, хранившихся у общих друзей» (курсив мой. - В. К.) [Семенко: 487].

Пушкинские пометы имели в основе редакторскую установку. А. Ю. Балакин разделил пушкинские пометы на семь разновидностей:

1) «оценки того или иного стихотворения, записанные, как правило, после текста, в нижней части страницы»;

2) «односложные в большинстве своем пометы такого же характера, относящиеся к той или иной строчке, обороту или периоду»;

3) «подчеркивания без каких-либо оценок (хотя в отдельных случаях Пушкин явно отмечает неудачные рифмы); кроме подчеркивания отдельных слов и строк сюда же надо поместить и отчеркивания на полях целых строф»;

4) «группа помет, которыми Пушкин не только указывает на неудачное, по его мнению, место, но предлагает, как его исправить»;

5) «вычеркивания - как отдельных строф, так и больших периодов»;

6) «заметки историко-литературного и мемуарного характера; их меньше всего, но они наиболее известны и чаще всего цитируются»;

7) «указания на источники переводов, подражаний и цитат, разночтения с предыдущими публикациями и пометы атрибуционного характера» [Балакин: 13-15].

В данном случае важно, подчеркивает исследователь, что «большинство пушкинских помет имеют отнюдь не полемический, а скорее редакторский характер» (курсив мой. - В. К.) [Балакин: 16]. Для «полемических» (в спорах с поэтами«батюшковианцами») ни к чему вычеркивать из текстов неудачные строки или фрагменты стихов, отмечать разночтения, предлагать свои исправления и т. д. Если бы целью Пушкина была полемика с «учениками» Батюшкова, он бы непременно использовал примеры из прозаических манифестов поэта (в его экземпляре «Опытов...» обе части были переплетены в один том [Майков: 290]) - но никакого интереса к полемическим 
суждениям в батюшковских статьях он не проявил, оставаясь редактором именно стихотворного текста.

Полемические оценки стихов Батюшкова Пушкин приводит лишь в пометах, отнесенных Балакиным к первой и шестой разновидности.

«Послетекстовых» пушкинских замечаний около трех десятков. Здесь даются прежде всего общие оценки стихотворений в целом - иногда очень суровые, иногда восторженные. Так, стихотворение «К друзьям», открывающее книгу - оценивается неудовлетворительно: «Весьма дурные стихи», а второе («Надежда») - «прекрасно». Следующее за ним - «На развалинах замка в Швеции»: «Вообще мысли пошлые, и стихи не довольно живы». А рядом («Элегия из Тибулла»): «Прекрасный перевод». И далее - Пушкину как будто важно лапидарно представить собственное эстетическое ощущение от восприятия конкретного текста: «Прелесть и совершенство - какая гармония!» («Тень друга»); «По чувству, по гармонии, по искусству стихосложения, по роскоши и небрежности воображения - лучшая элегия Батюшкова» («Таврида»); «Не стоит ни прелестной прозы Парни, ни даже слабого подражания Мильвуа» («Источник»), «Сильное, полное и блистательное стихотворение» («К другу»); «Преглупая пиеса» («Послание г. В-му»); «Цель послания не довольно ясна; недостаточно то, что выполнено прекрасно» («Послание И. М. М.-А.»); «Вот Бат<юшковск>ая гармония» («Радость»); «Лучшее стихотворение поэта - сильнейшее, и более всех обдуманное» («Переход через Реин») - и т. п.

Очевидно, что приведенные «оценки» имеют не полемическую, а именно редакторскую направленность. Пушкин откровенно высказывает кому-то собственное мнение о конкретном поэтическом тексте - а кто-то другой должен решить, включать ли этот текст в состав литературного наследия поэта или не включать.

Ту же цель как будто имеют маргиналии «историко-литературного и мемуарного характера». Пушкин отмечает, какие стихи ценит П. А. Вяземский («Пленный»), какие «кажется, несправедливо» осуждал И. И. Дмитриев («Тень друга»), над какими иронизировал П. А. Катенин («Мечта»), какие оказываются 
неловким подражанием Д. В. Давыдову («Разлука»), какие оказываются «достойны» В. Л. Пушкина («Послание к Т-ву») и т. д. Цель этих «мемуарных» апелляций, в принципе, та же, что и в «послетекстовых» оценках: представить широкую панораму восприятия конкретных произведений Батюшкова не только самим Пушкиным, но и «знатоками»-современниками.

Но в этом же «мемуарном» кругу «на равных» присутствует и личность самого Батюшкова - как литературная, так и биографическая: «Вот стихи прелестные, собственно Батюшкова - вся строфа прекрасна» («На развалинах замка в Швеции»); «Писано в первой молодости поэта» («Воспоминание»); «Одна из лучших элегий Б<атюшкова>» («Выздоровление»); «В. Л. Д<авыдов> в плену у французов говорил одной женщине: rendez-moi mes frimas. Б<атюшкову> это подало мысль написать своего Пленного...»; «немного опять похоже на Б<атюшкова>»; «Как неудачно почти всегда шутит Б<атюшков>! Но его Видение умно и смешно» («Ответ Т-ву») и т. д.

Эти «мемуарные» упоминания имени автора изучаемой книги производят двойственное впечатление. С одной стороны, они свидетельствуют о тесном дружеском общении Пушкина с Батюшковым: Пушкин знает, какие именно стихи из книги были для самого Батюшкова «любимыми», а какие «писаны в молодости», как именно сам поэт называл свои стихи, какие эпиграммы принадлежат Батюшкову, а какие нет и т. д. Но, главное: он внутренне чувствует Батюшкова-поэта, видит, где он подлинный («собственно Батюшков», «опять похоже на Батюшкова»), а в каких местах отдаляется от лирической «подлинности». С другой стороны, Батюшков присутствует в пушкинских пометах исключительно «в третьем лице» - мы даже не можем, например, «реконструировать» дружеское общение двух поэтов: на «вы» они обращались друг к другу или на «ты»? И почему именно «Опыты в стихах» заняли в общении поэтов роль некоего особенного «знака»?

\section{«...охота печатать всякой вздор! Б<атюшков> - не виноват!»}

История с изданием «Опытов в стихах и прозе» привнесла в жизнь К. Н. Батюшкова существенное беспокойство. 
Вообще о собрании своих сочинений воедино поэт задумался, едва обретя литературную известность. В 1810-1811 гг. в записной книжке «Разные замечания» поэт составил два списка: «Сочинения в прозе» и «Расписание моим сочинениям» [Батюшков: 21, 28-29]. Из первого списка остались неизвестными три текста, из второго - десять. Но работа над составлением собственного собрания началась неожиданно.

В августе 1816 г., выйдя в отставку с военной службы и живя в Москве, Батюшков получил письмо от Н. И. Гнедича из Петербурга: тот предложил выступить издателем сочинений своего приятеля. Подумав, поэт принял это предложение, хотя с материальной точки зрения оно было невыгодным: главную роль в этом решении играло то, что Батюшков ценил аккуратность Гнедича, а тот брал на себя редакторские заботы. Он сообщает Гнедичу из Москвы, что «мог бы печатать здесь», но боится, что книгопродавцы «изуродуют издание», а ему самому заниматься редактированием некогда: «Дела требуют моего присутствия в деревне, одна болезнь удерживает». И далее: «Мне ты учинишь одолжение, без тебя не решусь печатать. Ты знаешь мою лень и нерешимость» [Батюшков: 400-401]. Осенью 1816 г. поэт выслал для издания «том прозы», который был уже «готов, переписан и переплетен», и отправился в деревню работать над новыми стихами. Прежние стихи он предоставил собирать Гнедичу по журнальным публикациям.

Прозаический и стихотворный тома «Опытов...» (предполагалось выпустить «обе книги вдруг») вышли с перерывом в пять месяцев: Батюшков, находившийся в деревне, все тянул с отсылкой новых стихов. И отвергал предложения Гнедича по поводу прежних текстов: «ЛЛету” (сатиру «Видение на брегах Леты». - В. К.) ни за миллион не напечатаю...» «Эпиграмму: "Как странен здесь судеб устав" и проч. выбрось. Другую оставь на Ших<матова>, но назови ее: "Совет эпическому стихотворцу”. Басню "Сон могольца", "Книги и журналист" и еще кое-что выкинь»; «Теперь спешу объявить вам, что ни перевода из Тасса, ни из Ариоста не хочу. Особенно Тасс дрянь. Ты меня взбесишь! И сохрани Бог! Элегию "Умирающий Тасс" пришлю. Она имеет предисловие на страничке и стихов 
около 200 почти александрийских»; «Я ничего не могу поправить в стихах, и резон прекрасный: у меня все сожжено, и ни строки нет!.. Дряни ой как много!»; «Советую элегии поставить в начале. Во-первых, те, которые понравятся более; потом те, которые хуже, а лучшие в конец. Так, как полк строят. Дурных солдат в середину»; «Вот и мои стишки. Так, это сущая безделка! Посланье к Никите Муравьеву, которое, если стоит того, помести в книге, в приличном оному месте, а за то выкинь мою басню, либо какую-нибудь другую глупость» [Батюшков: 397, 431, 436, 439, 446, 449].

Батюшкова терзает неуверенность в успехе. Колебания продолжаются до последнего момента. Уже когда часть тиража второго тома была сброшюрована, по распоряжению автора вырезаны эпиграммы «Известный откупщик Фаддей...», «Теперь, сего же дня...», «О хлеб-соль русская...» и стихотворение «Отъезд»; а монументальные элегии «Переход через Реин» и «Умирающий Тасс» попали в самый конец сборника. Из поэтического наследия Батюшкова в «Опыты» отобрано пятьдесят два стихотворения (только до нас дошло более ста шестидесяти). Но автор все равно пребывает в неуверенности: «много дряни» и «глупости».

В июне 1817 г., узнав, что в Петербург (где книга стихов уже набирается в типографии) приехал В. А. Жуковский, Батюшков пишет ему большое «просительное» письмо:

«Теперь нужда заставляет писать. Гнедич издает мои проказы. Если есть у тебя лишнее время, взгляни на стихи и поправь и выкинь (это главное) все лишнее, на что, конечно, издатель мой согласится. Ты не поверишь, как эта затея меня мучит: издаю заочно, а сам в хлопотах. До стихов ли? Будь же снисходителен, милый друг, исполни мою просьбу. Если есть у тебя свободный часок, то скажи мне, что понравилось тебе и что не понравилось. Здесь в лесу не у кого спрашивать; я начинаю страшиться за талант мой, не сбился ли он с доброго пути? <...> Зачем я вздумал это печатать. Чувствую, знаю, что много дряни; самые стихи, которые мне стоили столько, меня мучат» (курсив мой. B. К.) [Батюшков: 441].

Свою неуверенность автор «Опытов...» объясняет спецификой собственного стихотворства. Он признается: «...я люблю 
славу и желал бы заслужить ее, вырвать из рук Фортуны. Не великую славу, нет, а ту маленькую, которую доставляют нам и безделки, когда они совершенны». Он ощущает, что «заочное» издание не может претендовать на «совершенство» и тут же высказывает идею о «втором издании» (хотя и первое издание еще не вышло в свет): «Если Бог позволит предпринять другое издание, то я все переправлю; может быть, напишу чтонибудь новое. Мне хотелось бы дать новое направление моей крохотной музе...» (курсив мой. - В. К.) [Батюшков: 441-442].

После же выхода в свет и шумного читательского и критического успеха «Опытов...» мысль о «другом издании» не только не оставила поэта, но, по закону парадокса, еще более укрепилась. Она соответствовала особенностям поэтической работы Батюшкова. Еще в ноябре 1811 г. в письме к Гнедичу он сочувственно приводил анекдот о поэте М. М. Хераскове:

«Покойник Херасков, сей водяной Гомер, любил давать советы молодым стихотворцам и, прощаясь с ними, всегда говорил, приподняв колпак: “Чистите, ради Бога, чистите, чистите! В этом вся и сила. Чистите! О! чистите, как можно более чистите, сударь! Чистите, чистите, чистите!..”»

И далее в письме - советы и «поправки» к присланному стихотворению Гнедича [Батюшков: 187]. А в 1816 г. в ответ на просьбы Гнедича скорее присылать стихотворный том «Опытов...», - писал: «Стихам не могу сказать: Vade, sed incultus (Иди, хоть и неотделанная. - лат.). Надобно кое-что исправить» [Батюшков: 409].

В конце концов, идея «другого издания» стихотворного тома стала для Батюшкова почти маниакальной. В этот период он и сблизился с «маленьким Пушкиным, которому Аполлон дал чуткое ухо» [Батюшков: 499]. Общение поэтов датируется пребыванием Батюшкова в Петербурге («Август, 25 (?) - Декабрь, 1 (?)» 1817, «Январь, 9 (?)...Май, 11» 1818, «Октябрь, 10...15 - Ноябрь, 19» 1818 [Летопись: 119, 129, 141]). Оно было довольно бурным: заседания «Арзамаса», поездки в Царское Село, проводы П. А. Вяземского в Варшаву и Жуковского в Москву, экспромты, совместные шалости. 19 ноября 1818 г. Пушкин был в группе друзей, провожавших Батюшкова, 
уезжавшего в Италию, - и даже сочинил не дошедший до нас экспромт ${ }^{2}$.

Следы этого общения двух поэтов сохранились и в литературных «легендах», подробно разобранных нами в работе, в основу которой лег специальный курс для псковских учителей [Кошелев, 1995]. Важно, что оно происходило на фоне выхода в свет (в начале октября 1817 г.) и особенно активного обсуждения в литературных кругах стихотворного тома «Опытов...». Литературные беседы Батюшкова и Пушкина поневоле должны были идти вокруг новой книги. Возникала и тема «другого издания», и желание «почистить»: Батюшков ценил всякое «чуткое ухо» в современной поэзии. И, естественно, мог обратиться к «Пушкину молодому» с просьбой, аналогичной той, с которой еще в июле 1817 г. обращался к Жуковскому.

То, что Пушкин был знаком с обстоятельствами составления и отбора текстов для «Опытов в стихах», явствует из той пометы, которая приведена в заглавии этого раздела. Она относится к «Посланию к Т<ургене>ву». Батюшков никак не думал о том, что этот текст войдет в его стихотворный сборник. По существу, это был большой (66 стихов) стихотворный экспромт из письма к А. И. Тургеневу от 14 октября 1816 г. («Ей-ей, impromptu!..» [Батюшков: 408]), в котором содержалась конкретная просьба выхлопотать «пенсион» вдове умершего в Москве офицера. Экспромт так понравился адресату, что он, удовлетворив ходатайство, отдал его в печать в «Пантеон русской поэзии»³. А уже оттуда Гнедич (без ведома автора) включил его в «Опыты...».

Пушкин оценивает «Послание к Т<ургене>ву», явно зная эту историю. Он отыскивает в непритязательном экспромте неудачные выражения - и рядом ставит самые язвительные пометы: «Какая холодная шутка!», «Что за слог!», «стихи, достойные $\mathrm{B}<$ асилия $>$ Л<ьвовича $>$ ». А, обратив внимание на заключительные стихи экспромта:

Они пред образом, конечно, Затеплят чистую свечу, За чье здоровье - умолчу: Ты угадаешь, друг сердечной! - 
не удерживается от иронического замечания: «Я не угадаю: если за здоровье Т<ургене>ва, то это плоско - если нет, так изъяснись - охота печатать всякой вздор! Б<атюшков > - не виноват» (курсив мой. - В. К.) [Пушкин, 1949: 275]. Батюшков действительно был не виноват: он доверился литературному вкусу Гнедича, а издатель, озабоченный (судя по сохранившимся письмам Батюшкова к нему) прежде всего тем, «что том стихов по милости Феба худощав» [Батюшков: 431], вставил в него без ведома автора, «много дряни».

При этом показательно, что и Батюшков, и Пушкин мыслят, что называется, в одном направлении. Возле стиха «Они очутятся с рублями» Пушкин делает замечание: «как плоско!». А Батюшков, когда принялся за подготовку нового издания «Опытов...», исправил прежде всего этот стих: «Они очутятся с сергами».

\section{«...выкинь все дишнее»}

В 1820-1821 гг., в состоянии надвигавшейся депрессии, Батюшков начал работу по подготовке другого издания: сохранился экземпляр с правкой автора (ОР РНБ. Ф. 50. Ед. хр. 18) ${ }^{4}$. Книгу «Опыты в стихах» предполагалось даже назвать иначе («Стихотворения К<онстантина > Б<атюшкова>»). Автор исправил некоторые опечатки, произвел перемещения текстов по своим разделам, ввел новый раздел («Переводы из Антологии»), в который предполагалось включить тексты, вошедшие в «арзамасскую» брошюру «О греческой антологии», и шесть новых, тут же вписанных стихотворений («одражания древним»). В качестве предисловия предполагалось перенести из прозаического тома «Опытов...» «Речь о влиянии легкой поэзии на язык». Тексты подверглись небольшой правке - но она не была доведена до конца.

Из состава стихотворного тома Батюшков вычеркнул десять стихотворений: «Тибуллова элегия III. Из III книги», «Веселый час», «К П-ну», «Сон воинов. Из поэмы Иснель и Аслега», «Сон могольца» и 5 (из 12-ти) текстов раздела «Эпиграммы, надписи и прочее». Некоторые из зачеркнутых первоначально текстов автор восстановил: так, возле зачеркнутого стихотворения «Вакханка» - помета Батюшкова: «Вычеркнуто ошибкою. Печатать». Но и эту работу, кажется, не завершил: некоторые 
В. А. Кошелев

откровенно слабые тексты (например, большая элегия «Мечта») были знаковыми для его внутренней творческой эволюции: написав «Мечту» в 1802-1803 гг., поэт потом многократно возвращался к ее тексту, дорабатывая стихотворение (ср. в письме к В. А. Жуковскому от 26 июля 1810: «Я к “Мечте” прибавил Горация: кажется, он у места...» [Батюшков: 140]). Вообще же в «Опытах...» была представлена уже́ четвертая редакция «Мечты» - плод размышлений полутора десятилетий: как его выбросишь?

Пушкин в своих пометах на книге Батюшкова, кажется, проделал подобную же работу. В оглавлении стихотворного тома «Опытов...» он пометил все заглавия либо черточкой, либо «ноликом» (без всякого знака оставлено - вероятно, по небрежности - только заглавие «Переход через Реин, 1814»). «Ноликами» отмечены стихотворения «Дружество», «Веселый час», «Судьба Одиссея», «На смерть супруги К-на», «К П-ну», «Хор для выпуска благородных девиц Смольного монастыря» и «Сон воинов». Показательно, что именно эти стихи остались единственными в сборнике, к которым в самом тексте никаких помет нет (см.: [Пушкин, 1949: 425]).

«Редакторский» смысл помет в оглавлении «прочитывается» однозначно: те стихи, которые помечены «ноликами», необходимо было просто выкинуть, - а по поводу остальных можно еще разбираться, отделив злаки от плевел. Отметим, кстати, что в двух случаях Пушкин и Батюшков «совпали», убрав из сборника одни и те же тексты. Столь же пристрастно Пушкин оценил и батюшковские «эпиграммы-надписи»: 5 из 12 текстов просто перечеркнул, а две - снабдил язвительными замечаниями («Переведенное острословие - плоскость» и «Какая плоскость!»).

Как бы то ни было, перед нами образец очень яркой работы Пушкина над текстами другого поэта - работы, имеющей именно редакторскую направленность. Подобное «сплошное» изучение чужого сборника, с оценкой буквально всех произведений, в этот сборник вошедших, - бессмысленно и в случае чтения его «для себя», и в каких бы то ни было «полемических» целях. Объективный смысл пушкинских замечаний определил Н. Н. Зубков в своей работе об «Опытах...» Батюшкова: «Пушкин сделал 
то, на что не решились, несмотря на просьбу автора, ни Жуковский, ни Вяземский, ни даже Гнедич, - отредактировал сборник, последовательно и тщзательно». Это редактирование, констатировал ученый, «совпадает с батюшковской самооценкой». Поэтому «критический разбор “Опытов...”, осуществленный Пушкиным, - самый заметный эпизод в истории их читательского восприятия, да и в практике Пушкина $\mathcal{M b l}$ не знаем другого примера сплошного чтения книги стихов с карандашом в руках» (курсив мой. - В. К.) [Зубков: 336-337].

Совершенно ясно, что такая работа не могла быть, что называется, «одномоментной»: помимо внимательного, целенаправленного чтения, она требовала глубоких размышлений. А сама пестрота оценок этого «критического разбора» свидетельствует, что они вносились в экземпляр «Опытов...» в разное время - иногда с большими перерывами. Если говорить о целеполагании и прагматике подобной работы, то она могла быть продиктована естественным желанием Пушкина представить стихи поэта-предшественника - в вожделенном «другом издании» - в том виде, в каком бы они соответствовали замыслу Батюшкова: в отношении к этому «идеалу» пушкинская редактура была адекватной.

А. Ю. Балакин в недавнем исследовании представил гипотезу, что таким «другим изданием» были вышедшие в 1834 г. двухчастные «Сочинения в прозе и стихах» Батюшкова, изданные И. И. Глазуновым. В него вошли некоторые новые прозаические («Предслава и Добрыня») и 23 стихотворных текста поэта, не входившие в «Опыты...», а также восемь его частных писем к друзьям, «литературная» ценность которых осознавалась еще при жизни Батюшкова. Балакин проделал большую работу, исследовав с этой точки зрения «ситуацию 1833 года» и гипотетически «вычислив» инициатора издания (С. С. Уваров) и его редактора (П. А. Плетнев). По просьбе последнего Пушкин и «подключился» к редакторской работе.

Наблюдения ученого, часто меткие и оригинальные, все же рождают существенные вопросы. Во-первых, если попытаться «наложить» реконструированную Балакиным «ситуацию 1833 г.» на хронику пушкинской жизни в этот период (обобщенную в работе С. Абрамовича «Пушкин в 1833 году» [Абрамович]), то 
окажется, что в этот период у Пушкина совершенно не было времени для кропотливой редакторской работы: он не мог, занятый службой, семьей, добыванием денег, разъездами, историческими штудиями и т. д., отвлечься на «исправление» стихов поэта-предшественника, который уже перестал осознаваться живым литературным явлением. Кроме того, в тот самый период, когда работа над сборником шла особенно активно летом и осенью 1833 г., - Пушкин вообще был далеко от Петербурга: с 17 августа до 20 ноября он был в поездке по «пугачевским» местам и в Болдино [Летопись: 73-113].

Во-вторых - и главное: ни одно из пушкинских замечаний, высказанных в результате кропотливой редакторской рабоmbl, - в «Сочинениях...» 1834 2. не было учтено. Если принять тезис, что «пометы Пушкина предназначались для Плетнева, который приступил к подготовке нового издания сочинений Батюшкова и обратился к Пушкину с просьбой помочь ему в этой работе, высказать свои суждения о составе будущего сборника, отметить неудачные стихи и сократить длинноты» [Балакин: 23] — то с этим никак не согласуется итог: «...пушкинские замечания остались неучтенными в издании 1834 года» [Балакин: 26].

И объяснение исследователем этой точки зрения кажется двусмысленным: «Возможно, дело было в разнице взглядов на творчество Батюшкова: для литератора Пушкина это был живой собеседник, волею судеб не успевший тщательно подготовить к печати собрание своих сочинений; Плетнев же, вероятно, смотрел на наследие впавшего в безумие поэта как филолог, стараясь представить его публике с дипломатической точностью: для него это был уже “литературный памятник”. Не исключено также, что в редакционный процесс мог вмешаться и Уваров, отношения которого с Пушкиным с весны 1834 года стали едва ли не враждебными» [Балакин: 26].

Но в этой ситуации вряд ли Плетнев, с пиететом относившийся и к Батюшкову, и к Пушкину, стал бы обращаться к последнему с подобной просьбой: любые «замечания» Пушкина возле стихов Батюшкова невозможно было бы использовать в «другом издании». А если бы Плетнев все-таки уговорил Пушкина и потом никак не использовал результатов 
его кропотливого труда, - то и это обстоятельство непременно «отложилось» (хотя бы косвенно) в документальных свидетельствах (например, в известном «Дневнике» Пушкина 1833-1835 гг.).

Во всяком случае, полностью осуществить в издательской практике ту правку нашумевшего в 1817 г. стихотворного сборника, которую наметил Пушкин, имел право и возможность только один человек - сам Батюшков. Вмешательство в этот процесс какого-либо другого лица выглядело бы и безнравственным, и противоестественным. Так что поневоле приходится отыскивать «другое издание» «Опытов...» в гипотетическом ряду тех сборников Батюшкова, которые не состоялись.

\section{«Прощай, Поэт»}

Косвенным доказательством того, что основная работа с редактированием «Опытов...» завершилась у Пушкина раньше 1833 г., становится его переписка с братом Львом и тем же Плетневым от весны 1825 г. Те выступили «комиссионерами» по изданию его первого сборника стихотворений. Пушкин отказался от печатания «тетради Всеволожского» и собрал подборку из 60 «новых и старых стихов»:

«Я выстирал черное белье наскоро, а новое сшил на живую нитку. <...> В порядке пиес держитесь также вашего благоусмотрения. Только не подражайте изданию Батюшкова - исключайте, марайте сплеча. Позволяю, прошу даже» (курсив мой. В. К.) [Пушкин, 1937: 153].

Это пожелание содержится в письме от 15 марта 1825 г.

В следующем письме (от 27 марта) Пушкин шутливо пересказывает основные идеи будущего «предисловия»:

«Вот в чем должно состоять предисловие: Многие из сих стихотворений - дрянь и недостойны внимания россейской публи$\kappa и$ - но как они часто бывали печатаны бог весть кем, черт знает под какими заглавиями, с поправками наборщика и с ошибками издателя - так вот они, извольте-с кушать-с <...>. Мы (сиречь издатели) должны были из полного собрания выбросить многие штуки, которые могли бы показаться темными, будучи 
написаны в обстоятельствах неизвестных или малозанимательных для почтеннейшей публики (россейской) или могущие быть занимательными единственно некоторым частным лицам, или слишком незрелые...» (курсив мой. - В. К.) [Пушкин, 1937: 157-158].

Указав на основной недостаток стихотворного тома «Опытов...», отмеченный также и в интересующих нас пометах (отсутствие необходимого критического отбора произведений), Пушкин заодно объясняет, каким образом в лирический сборник, представляющий серьезного автора, проникают всякая «дрянь», «глупость», «вздор», «пошлость» и т. д. Многие стихи появлялись прежде «черт знает под какими заглавиями, с поправками наборщика и с ошибками издателя» и отложились в сознании публики в этом виде. Другие были связаны с «малозанимательными» для большинства публики обстоятельствами (вроде экспромта, посланного по частному поводу Тургеневу — и «украсившему» поэтический сборник) они просто «неинтересны» большинству людей. Третьи вообще были созданы «в первой молодости поэта» - а кому, в сущности, интересны штудии 14-летнего мальчика?

Все эти «отрицательные» моменты функционирования отдельных поэтических текстов внутри единого сборника Пушкин изучил, редактируя именно «Опыты в стихах» Батюшкова.

Наша гипотеза состоит в том, что пушкинские пометы были вызваны соответствующей просьбой самого Батюшкова и свидетельствуют о многократном обращении Пушкина к этому сборнику. 19 ноября 1818 г. Батюшков выезжал из Петербурга в Неаполь, к новому месту службы; он был исполнен многих творческих надежд. Пушкин был в числе провожавших его. Очень вероятно, незадолго перед тем Батюшков просил молодого и чуткого поэта «почистить» его стихи, дабы по возвращении «предпринять другое издание». После же этой даты Пушкину не суждено было увидеть Батюшкова в здравом рассудке.

Он серьезно отнесся к просьбе уважаемого им поэта: проведенная им редакторская работа несет в себе не столько собственно «пушкинскую», сколько «батюшковскую» направленность (ее имеют как минимум 170 помет). Какой смысл «для себя» делать пометы типа: «прекрасно», «вяло», «лишний стих», «неудачный перенос», «ошибка мифологическая», «галлицизм» 
и т. д.? Такого рода замечания и часто прямые исправления делать «для себя» бессмысленно. Другое дело: для будущих штудий Батюшкова. К стиху «Как ландыш под серпом убийственным жнеца» («Выздоровление») делается замечание: «Не под серпом, а под косою. Ландыш растет на лугах и в рощах не на пашнях засеянных» (курсив мой. - В. К.). Здесь нет противостояния «реалистической» и «романтической» поэтики (как указывали некоторые исследователи). Пушкин понял и принял батюшковскую аллегорию безвременно оборванной жизни - но это не мешало указать на фактическую ошибку.

Подобные примеры многочисленны. В стихотворении «Мщение» возле стиха «И жребий с трепетом читает» помета: «Должно было: свой жребий». В «Тибулловой элегии ХІ» выделен стих: «Иль на чело его в знак мирного венчанья» - и на полях находится помета чисто "редакторская»: «Увенчаем в знак венчания!!!». То же в стихотворении «Пробуждение»: выделяя стихи «И гордый ум не победит Любви, холодными словами», Пушкин поясняет: «Смысл выходит - холодными словами любви - запятая не поможет». И так далее.

Пушкин-редактор исходил из требований того поэтического направления, которое Л. Я. Гинзбург назвала «школой гармонической точности» [Гинзбург: 19-50]. Одним из основателей и лидеров этой школы был как раз Батюшков, а Пушкин ощущал себя ее верным учеником. Идеалом же этой «школы» было отсутствие «темных мест», сочетание лирической ясности и смелости.

Естественно, что единственным поэтом, которому было можно «исправить» замеченные «ошибки против вкуса» мог быть только сам Батюшков. Лишь автор мог оценить отмеченные огрехи и, если захочет, исправить их. На подобную «редакторскую» работу у Пушкина было вроде бы достаточно времени (до возвращения Батюшкова из Италии) - и он, время от времени, перечитывая с карандашом в руках стихи поэта-предшественника, заносил свои замечания в собственный экземпляр книги. Пометы в «Опытах...» стали единственным дошедшим до нас примером такой работы Пушкина с поэтическим сборником. Известно еще, что он в 1824 г. занимался «построчным разбором» поэмы К. Ф. Рылеева «Войнаровский» (на полях 
экземпляра поэмы - см.: [Пушкин, 1937: 160, 174, 183]) и высказал не дошедшие до нас «прямодушные замечания».

Летом 1822 г. в Кишиневе Пушкин узнал о душевном заболевании Батюшкова - и воспринял эти известия в штыки: «Мне писали, что Батюшков помешался: быть не льзя; уничтожь это вранье» [Пушкин, 1937: 42]; «Батюшков в Крыму. Орлов с ним видался часто. Кажется мне, он из ума шутит» [Пушкин, 1937: 54]. И только в Михайловской ссылке - когда отвергать слухи стало уже невозможно - заявил (в письме к Рылееву от 25 января 1825): «Что касается до Батюшкова, уважим в нем несчастия и не созревшие надежды. Прощай, Поэт» [Пушкин, 1937: 135].

Эта фраза, отметил современный исследователь, имеет «двойной адрес и двойной смысл. Пушкин спорил с Рылеевым и Бестужевым, критически отозвавшимися в “Полярной звезде” о его наставниках - Жуковском и Батюшкове. Но одновременно, как это часто бывало у Пушкина, он фиксировал собственные мысли, пытался понять различие между двумя корифеями. И если оценка заслуг Жуковского, данная в письме Рылееву, безоговорочна: “Жуковский имел решительное влияние на ход нашей словесности”, - то сделанное Батюшковым, по мнению Пушкина, дает повод говорить лишь о “несозревших надеждах”. Пушкинскую характеристику Жуковского Рылеев оспорил, а с суждением о Батюшкове легко согласился: “Он точно достоин уважения и по таланту, и по несчастию”. Творчество Жуковского для декабристов - явление, с которым надо бороться, Батюшков же им, по существу, безразличен» [Зубков: 336].

К середине 1820-х гг. Батюшков уже перестал осознаваться живым действующим лицом в русской словесности - именно из-за его «несчастия» новые литераторы представляли поэта в качестве этакого «литературного памятника». Сможет ли он войти в прежнюю поэтическую «форму», осмыслить и исправить те «ошибки», которые отметил Пушкин? Вопрос этот оставался без ответа - и редакторская работа Пушкина становилась невостребованной (ибо предназначалась только и исключительно для самого Батюшкова). 
Но, судя по изучаемым пометам, Пушкин и тогда не оставил экземпляра «Опытов...».

\section{Феномен «домашней критики»}

Нашу гипотезу жестко критиковал О. А. Проскурин. Указав на определенную ценность ее (заключенную «в достаточно отчетливо проартикулированной мысли о том, что исследователи поныне не ответили на вопрос: зачем и для кого Пушкин делал пометы на “Опытах"?»), он начисто отверг предположение, будто эти пометы могли адресоваться самому Батюшкову.

Выбрав из пушкинских «редакторских» оценок наиболее негативные - «темно» (3 раза), «холодно» (2 раза), «проза» (2 раза), «неудачно» (2 раза), «слабо» (2 раза), «дурно» (8 раз), «дрянь» (5 раз) и т. п. - Проскурин почему-то решил, что «такие оценки явно доминируют в пометах "редакционного характера” над нейтральными и позитивными». Это не так: нетрудно сосчитать, что их не более трети от общего числа помет.

Далее исследователь обрушивается с уничтожающей критикой: «Такие оценки не всякий самовлюбленный мэтр мог бы позволить высказать в лицо неопытному ученику. И определенно такое не мог позволить себе Пушкин в 1818 году, какую бы самодовольную самоуверенность мы в нем ни предполагали. Отношения между Батюшковым и Пушкиным никогда не были фамильярно-дружескими; Пушкину же прекрасно был известен болезненно-обидчивый характер Батюшкова. Предназначать свои пометы для Батюшкова Пушкин мог бы только при одном условии - если бы хотел насмерть с ним рассориться... В таком намерении заподозрить его трудно». Словом, наше «умозрительное гипостазирование нередко заставляет в желаемом видеть действительное» [Проскурин, 2003: 261-262].

Эта насмешливая «рацея» представляется некорректной по двум причинам.

Во-первых, как показано нами в работе «В предчувствии Пушкина...» [Кошелев, 1995], отношения Батюшкова и «Пушкина молодого» в 1818 г. вовсе не были отношениями «мэтра» и «ученика» и подчас носили оттенок некоей фамильярности (см. еще: [Кошелев, 1988]) - при этом Батюшков отнюдь не 
проявлял «болезненно-обидчивого характера». Как показано выше, высказывая Пушкину просьбу об «исправлении» своего сборника, Батюшков просил его, имеющего «чуткое ухо», прежде всего освободить «Опыты...» именно от «дряни» и «глупостей». Осуществляя редактуру под знаком такого критического задания, Пушкин просто не мог быть «ласковее», отмечая найденные недочеты.

Во-вторых, О. А. Проскурин явно проецирует позднейшие литературные нравы на «пушкинскую эпоху», которая чаще всего представляла совсем иные возможности полемических выступлений. «Домашняя критика» той эпохи (одним из активных деятелей был как раз Батюшков, не проявивший себя в традиционных критических жанрах, не участвовавший в литературных полемиках своего времени, не отзывавшийся печатно о литературных новинках и т. п.), вырабатывала в начале XIX столетия особенную тональность критических оценок.

«Показательно, что в кругу друзей Батюшков был признанным редактором, ценителем и первым критиком только что написанных произведений: его мнение особенно ценили. Гнедич, Жуковский, Вяземский постоянно присылали ему свои новые вещи “для замечаний", для исправления “слога" и т. п. И часто использовали эти “замечания”: Жуковский в стихотворении “Императору Александру”, Вяземский в “Послании к Жуковскому”, “К подруге”, в элегии “Первый снег”" [Кошелев, 1999: 222]. Подобная «критика для немногих», предназначенная «для себя» и для узкого круга друзей, допускала тот тон отзывов и оценок, который с высоты нынешних представлений кажется недопустимым.

Вот единственный пример, число которых можно было бы многократно увеличить. В начале 1812 г. Батюшков послал своим друзьям, Жуковскому и Вяземскому, свое послание к ним - «Мои Пенаты». Вяземский - тогда еще начинающий поэт, «младший» по отношению к автору послания, не замедлил откликнуться (1 мая 1812 г.) письмом. Обратим внимание на развязную тональность конкретных указаний:

«О Пестуны мои!

Слово слишком государственно-секретарское, чтобы находиться в такой пиесе и особливо после слова Пенатов, которое 
Об одном давнем «парадоксе»: Жанр маргиналий А. С. Пушкина... 31

совершенно басурманское и слишком похожее на другое, так что, читая однажды даме, у меня вырвалось: о пердуны мои!

Походы прозвени
Про витязя с нагайкой!

Можно прозвенеть про походь, а не походы про.

И вкруг его рядами

Враги ложились в прах!

Сии два стиха не в связи с предыдущим.

В стихах о Ломоносове неприличен эпитет Исполина по двум причинам. Ломоносов, во-первых, такой же Исполин, какой Шаликов умница: он написал несколько прекраснейших строф и только; а во-вторых, потому, что после сравниваешь ты его с лебедем.

Стихи твои о Карамзине несносны: что за “перо из крыльев Леля”? Что ты за Бланк такой, чтоб красть, и у кого еще: у Панкратья Сумарокова? Что за похвала Карамзину, что он перевел Мармонтелевы повести? Что за таблицы Мнемозин? Что значит таблицы? Что за Мнемозины, когда все, даже и Макаров, знают, что только одна Мнемозина?

Важных $M y 3$

Еще хуже: Строгих Муз. Музы никогда не думали пугать и никогда не хотели быть ни Екатериной Владимировной Апраксиной, ни Настасьей Дмитриевной Афросимовой!»

И так далее [Вяземский, 1994: 132-133].

Показательно, что подобные оценочные реплики, высказанные в отношении классического дружеского послания, не вызвали у Батюшкова ни обиды, ни желания спорить. Напротив, в ответном письме он признал:

«Впрочем, замечания твои справедливы, и за них спасибо. <...> Придумай еще сам кое-что поправить, если только это стоит того» [Батюшков: 214].

Автор тут же внес необходимые поправки - в частности, убрал строки о Карамзине из первоначальной редакции послания («Пером из крыльев Леля / Здесь пишет Карамзин, / 
Преемник Мармонтеля, / В таблицах Мнемозин»), вызвавшие особенно язвительные замечания приятеля.

Показательно, что такая «домашняя» критика совершалась «на людях»: письмо Вяземского в Москве читал В. Л. Пушкин (оно содержит приписку от него), а в Петербурге Батюшков первым делом «прочитал его Блудову, который на ту пору случился у меня» [Батюшков: 213]. Такого рода «домашние» отношения среди «арзамасцев» были забыты в позднейшем литературном быту. Нелицеприятные пушкинские пометы были делом совершенно обыкновенным - и никак не могли вызвать у Батюшкова желания «насмерть рассориться» с Пушкиным, буквально выполнявшим его «критическое задание».

\section{«Настоящее грамматическое время»}

В. Б. Сандомирская выделила - среди «развернутых» и «мемориальных» помет - три, относящиеся к самому Батюшкову: «Любимые стихи Бат<юшкова> самого» (возле элегии «Таврида»); «Как неудачно почти всегда шутит Б<атюшков >! Но его Видение умно и смешно» («Ответ Тургеневу»); «Монгольская басня, как называет Б<атюшков> сам» («Сон могольца»). «Общей чертой этих помет является употребление в них настоящего грамматического времени» указывает исследователь и делает вывод, что для автора помет Батюшков - «безусловно, действующее лиио в современной поэзии...» (курсив мой. - В. К.) [Сандомирская: 31].

Но что интересно: когда в тех же пометах, в подобных же «мемуарных» упоминаниях встречаем имена других современников Пушкина - тоже «живых и действующих», и даже находящихся в здравом рассудке - то они поминаются в прощедщем времени: «Дмитриев осуждал цезуру этих стихов. Кажется, не справедливо» (по поводу первых двух стихов элегии «Тень друга»); «Любимые стихи к<нязя $>$ П. Вяземского» (два стиха из «Пленного») «Катенин находил эти два стиха достойными Баркова» (по поводу неудачного выражения из элегии «Мечта») [Пушкин, 1949: 262, 265, 270].

В рамках нашей концепции кажется неожиданным, что в пометах, предназначенных для Батюшкова, сам Батюшков присутствует «в третьем лице» - как фигура, от этих помет 
отстраненная. Это выглядит естественно в «редакторских» замечаниях, вроде того, которое поставлено рядом со стихами из послания «Ответ Г-чу» («Твой друг тебе навек отныне / С рукою сердце отдает»): «Б<атюшков $>$ женится на Г<недич>е!». Или в замечании по поводу элегии «Мщение»: «И у Парни это место дурно, у Б<атюшкова> хуже. Любовь не изъясняется пошлыми и растянутыми сравнениями». А затем дается французская цитата из Парни (соответствующая переводу Батюшкова) и замечание: «Какая разница!» [Пушкин, 1949: 275, 260-261].

Но вот — «приговор» любимой автором «Опытов...» элегии «Мечта»: «писано в молодости поэта. Самое слабое из всех стихотворений Б<атюшкова>» [Пушкин, 1949: 272]. Эти слова свидетельствуют, между прочим, о глубоком знакомстве Пушкина с творческой историей этого - самого раннего - стихотворения Батюшкова (написанного в 1802-1803 гг.). Первая редакция элегии (заключавшая в себе 89 стихов) была напечатана еще в 1806 г.; потом, в 1810 г., Батюшков напечатал ее в переделанном и расширенном виде. Затем элегия перепечатывалась в разных собраниях, постепенно разрастаясь. Для «Опытов» автор ее вновь дополнил: в этой редакции «Мечта» разрослась до 211 стихов. Текст увеличился за счет развития эротических мотивов, введения скандинавской («оссиановской») темы и т. д. При этом структурный принцип оставался неизменен: поэт, обращаясь к «мечте», нанизывал все большее количество эпизодов. При этом понятия «мечта» и «мечтанье» получали, в качестве дополнительного, значение воображение: сам Батюшков вкладывал в него программный смысл.

Ощущая юношескую «слабость» этого разросшегося творения, Пушкин не мог просто «отмахнуться» от него (обозначив, например, «ноликом» в оглавлении): он понимает, что значит оно для Батюшкова. И он детально вчитывается в него, зачеркивает неудачные стихи, делает по тексту около 30 замечаний - причем, не только «отрицательных» (типа «детские стихи», «дурно», «какая дрянь», «слабо», «вяло» и т. п.), но и «хвалебных» («гармония», «прекрасно», «хорошие 4 стиха» и т. д.). И, только проделав эту кропотливую работу, произносит приведенный выше «приговор», демонстрируя глубочайшее проникновение в творческую психологию автора, но 
вместе с тем понимая, что нельзя в качестве программного текста ставить то, что «писано в молодости поэта».

Батюшков и здесь присутствует в настоящем времени. Высказывания о его стихах современников (данные в прошедшем времени) оказываются хронологически зыбкими. Многие исследователи, пытаясь датировать пушкинские пометы, приспосабливали эту датировку к упоминаниям «умирающего Василия Львовича» или к замечаниям Дмитриева, Катенина или Вяземского - и оказывалось, что эти оценки не могли стать хронологическими ориентирами: подобные фразы не были «привязаны» к определенным годам. Но зачем эти имена вообще появились среди "редакторских» помет Пушкина? Для чего ему потребовалось «подкреплять» свое мнение авторитетом современников?

Представляется, что в этом случае деформировалась сама поэтика «маргинальных помет»: «редакторское» задание стало корректироваться «историко-литературными» и «мемуарными» деталями. Это обстоятельство, на наш взгляд, свидетельствует, что указанная (немногочисленная) группа помет появляется позднее - и указывает на то, что отношение к автору «Опытов...» у Пушкина уточняется. Батюшков продолжает присутствовать в его сознании «в третьем лице», - но непременно в настоящем времени.

Фигура Батюшкова отличается от прочих современников именно тем состоянием, в котором он находился: то ли «с ума сошел», то ли «из ума шутит». Душевная болезнь, поразившая поэта, - всего лишь болезнь, от которой можно излечиться (что друзья Батюшкова и пытались делать во второй половине 1820-х гг., подыскивая для поэта подходящее место лечения). Сейчас он действительно присутствует в этом мире исключительно в настоящем времени - но не исключено, что возвратится в реальное настоящее и вновь обратится к творчески пережитому прошедшему.

Батюшков был поэтом, более независимым от литературных «пристрастий» и «партий», чем многие его современники. Воспринимавшийся как литературная «гордость» «Арзамаса», он явно «перерастал» его полемические устремления. Формальная принадлежность к школе «легкой поэзии» 
придавала его творческому облику характерную литературную «окрашенность». Современники указывали, например, что Батюшков «разделял славу с Жуковским», - но только «между литераторами», среди которых представал в роли поэта для немногих (курсив мой. - В. К.) [Дмитриев: 193].

Поэтому особенно восторженные оценки Пушкина в изучаемых пометах («живо, прекрасно», «прелесть и совершенство», «какая гармония» и т. п.) относятся именно к «мелочам», к отдельным особенно удавшимся стихам («безделки, но важные для уха» - как называл их сам Батюшков), значимым именно для внутреннего «поэтического» восприятия.

Так, к стиху «Любви и очи, и ланиты» (элегия «К другу») Пушкин делает примечание как будто частное, но воспринимаемое как итоговая оценка: «звуки италианские! Что за чудотворец этот Б<атюшков>».

Р. М. Горохова указала на перекличку этой пометы Пушкина с фразой из статьи Плетнева «Письмо к графине С. И. С. о русских поэтах», напечатанной в «Северных Цветах на 1825 год»: «Игривость Парни и задумчивость Мильвуа, выражаемые какими-то Италианскими звуками, дают только понятие об искусстве Батюшкова» [Плетнев: 38]. В январе 1825 г. в Михайловском Пушкин читал эту статью. Связана ли с этим чтением помета «звуки италианские»? Пушкин ли воспользовался определением Плетнева? Плетнев ли опирался на слова Пушкина? или это было «случайным совпадением оценок»? По этому поводу высказывались противоположные мнения (см.: [Горохова: 38], [Проскурин, 2003: 266], [Балакин: 22-23]).

В 1985 г. музыковед Б. А. Кац посвятил этой помете большую заметку, в которой связал эту помету (точнее, «зияние гласных» в ней, ориентированное на итальянскую оперу с ee bel canto) и предположил (приведя ряд аналогичных примеров из высказываний Пушкина), «что восклицание “звуки италианские!” по своей глубинной семантике шире простой констатации эвфонического сходства стихов Батюшкова с итальянской поэзией и, во всяком случае, нагружено ассоциациями (возможно, подсознательными) с итальянской вокальной музыкой». В этом восклицании «допустимо увидеть не только слуховую 
чуткость стихотворца, но и упоение художника гармонией в любом ее проявлении» [Кац: 172].

В этом смысле Батюшков, идеальный носитель словесной «гармонии», оценивается Пушкиным как поэт «вне времени», далекий от сиюминутных литературных баталий. Пушкин, например, называет «умной и смешной» его сатиру «Видение на брегах Леты» (1809), в «Опыты...» не вошедшую. Пушкин совсем не случайно вспомнил эту сатиру. «Особая» позиция Батюшкова в ней заключалась в том, что автор не принимал сторону ни «архаистов», ни «новаторов», а брался судить современную поэзию с точки зрения извечной Леты, «реки забвения стихов»: только такой «отстраненный» от «сиюминутности» угол зрения давал возможность увидеть подлинные ценности. Именно этот ореол «чистого искусства» оставляет фигуру Батюшкова всегда в «третьем лице» и в настоящем времени.

\section{«Это не Бат<юшкова>, а Блуд<ова>, и то перевод»}

Самые острые и нелицеприятные пушкинские пометы возле раздела «Эпиграммы, надписи и пр.». Пять из двенадцати эпиграмм перечеркнуты целиком, возле двух - язвительные пометы типа: «Переведенное острословие - плоскость» («Мадригал новой Сафе»), а возле самой первой эпиграммы («Всегдашний гость, мучитель мой...») помета вообще загадочная: «Это не Бат<юшкова>, а Блуд<ова>, и то перевод» [Пушкин, 1949: 279].

О. А. Проскурин охарактеризовал ее как свидетельство того, что Батюшков, подчас, «варьировал или попросту повторял чужие шутки», и глубокомысленно отметил: «Эта помета, несомненно, имеет под собой какое-то основание» [Проскурин, 2000: 79]. Означает ли это, что Пушкин указал на некую «нечистоплотность» Батюшкова, зачем-то повторявшего «чужие шутки»? При этом помянутый Блудов никогда никаких претензий относительно принадлежности этого текста ему, а не Батюшкову, не предъявлял.

Давно выяснен французский источник этого «перевода»: эпиграмма П. Д. Экушара-Лебрена «О, la maudite compagnie...» («О, проклятая компания...»). Высказывались предположения, что эпиграмма относится к началу 1812 г., назывались даже 
«прототипы» высмеянного в ней «гостя» (стихотворец Г. П. Ржевский, некий учитель Турбин). Блудов действительно мог быть автором или, во всяком случае, «соавтором» этой эпиграммы, ибо жил в Петербурге, где в то время был Батюшков, и являлся одним из самых верных его почитателей. Он мог, например, «вовремя» вспомнить французский текст подходящей «к случаю» эпиграммы (или bon mot), которую Батюшков тут же перевел по-русски...

Пушкинское замечание демонстрирует прежде всего осведомленность поэта в мелочах взаимоотношений членов «арзамасского» кружка (Блудов, Батюшков, Тургенев и др.). Но это была, что называется, осведомленность «задним числом»: он не мог присутствовать при подобном эпизоде, послужившем поводом для эпиграммы. Он мог лишь услыщать от кого-то из участников этого события соответствующий «анекдот»: нечто похожее на то, что было предположено выше. Но тогда оказываются странными его представления об «авторстве»: подлинным «автором» «переведенного острословия» признается тот, кто вовремя и к месту «припомнил» оригинал, - а не тот, кто представил его перевод.

Как показано выше, Батюшков был неповинен в том, что «не его» эпиграмма попала в собрание его стихов, составлявшееся Гнедичем (в своем экземпляре «Опытов...» он ее потом вычеркнул). Но в свете пушкинского замечания она занимает странное «межеумочное» положение, принадлежа одновременно двум авторам! Такое положение художественного произведения противоречит современным представлениям об «авторстве», но находится вполне в традициях пушкинской эпохи, в которой подобная «дубиальность» выступала как вполне естественное явление (см.: [Кошелев, 2005]).

В связи с этим явлением особенный интерес для нашей темы приобретает фигура Дмитрия Николаевича Блудова, «душеприказчика» поэтического творчества Батюшкова. Блудов и Батюшков познакомились в начале 1812 г. в Петербурге - и уже с этого времени Блудов стал составлять список стихотворений поэта - так называемую «первую блудовскую тетрадь» (РО ИРЛИ. Ед. хр. 9654). Когда осенью 1812 г. Батюшков решил идти в армию, он завещал в письме Вяземскому: 
«Если же ты меня переживешь, то возьми у Блудова мои сочинения, делай с ними, что хочешь: вот всё, что могу оставить тебе» [Батюшков: 233]. Подобную же просьбу он повторил в письме к Гнедичу, охарактеризовав Блудова «как человека доброго, честного и умного - три редкие качества в наше время» [Батюшков: 234]. В 1815 г. была составлена «вторая блудовская тетрадь» (ОР РНБ. Ф. 50. Ед. хр. 11). Оба списка были авторизованы поэтом - и стали основными источниками его текстов.

Батюшков активно общался с Блудовым, всецело доверял ему, охотно включался в его предприятия. В июне-июле 1814 г. он гостил у Блудова в Стокгольме (тот служил статс-секретарем российского посольства в Швеции), потом вместе с ним ехал через Финляндию в Петербург. К 1817 г. относится их «арзамасское» общение. Летом 1821 г. Блудов посетил Батюшкова в Теплице, где поэт лечился на германских водах и находился в состоянии творческого подъема.

«Это посещение важно, - отметил В. Э. Вацуро. - Короткий друг Жуковского, поклонник Байрона, Блудов привозит Батюшкову литературные новости. Нужно иметь в виду одну особенность Блудова: он обладал удивлявшей современников почти фотографической памятью на стихи и мог читать наизусть целые трагедии - русские и французские. Он мог <...> запомнить прочитанные ему стихи» [Вацуро: 156-157]. Основные стихи Батюшкова последнего периода (которые поэт, впав в безумие, «все истребил») сохранились именно в памяти Блудова.

Среди них - блистательный перевод 178 и начала 179 строфы IV песни «Странствований Чайльд-Гарольда» Байрона «Есть наслаждение и в дикости лесов...». История издания и редактирования этой, последней элегии Батюшкова подробно описана В. Э. Вацуро. Текст, сохранившийся в памяти Блудова, оказался записанным в ряд светских альбомов. Потом он попал в записную книжку Вяземского за 1826 год [Вяземский, 1963: 131], - а Вяземский сообщил его Пушкину, по инициативе которого новое стихотворение Батюшкова было решено включить в очередной выпуск альманаха «Северные цветы на 1828 год». Для этого требовалось отредактировать недоработанный батюшковский перевод, дошедший к тому же в «изустной» памяти. 
В записи Вяземского текст состоял из 17 строк; в таком виде его узнают друзья поэта. В его редактировании в конце 1827 г., вероятно, принял участие еще и Жуковский (см.: [Вацуро: 163165]). Редактура была довольно жесткой: последние пять строк отброшены, после чего стихотворение приобрело завершенный вид, в шести (из двенадцати) стихах произведены замены: вместо «Ты сердиу моему дороже» - «Для сердиа ты всего дороже»; вместо «С тобой, владычица, я властен забывать» «С тобой, владычица, привык я забывать»; вместо «Их выразить язык не знает стройных слов» - «Их выразить душа не знает стройных слов» и т. п. (курсив мой. - В. К.). Сохранилась выполненная Пушкиным наборная рукопись отредактированного текста, идентичная тексту «Северных цветов» [Рукою Пушкина: 507].

Рассмотрев этот текст, Вацуро заметил, что, хотя он и не является подлинным текстом Батюшкова, «но для истории русской поэзии он имеет значение самодовлеющее, и не только из-за своего художественного совершенства. Он остается памятником “арзамасского” сотворчества, культурным феноменом, характерным для совершенно определенной эпохи литературного сознания, который мы определяем как "пушкинскую эпоху". И в этом своем качестве его целесообразно было бы сохранять в изданиях Батюшкова наряду с подлинным, объяснив читателю уникальные условия его появления» [Вацуро: 165].

Но интересно еще, что эту же элегию Батюшкова Пушкин еще раз переписал в экземпляре «Опытов...»- на отдельном листе в конце книги. Причем, в этом тексте имелись еще разночтения в сравнении с публикацией: вместо «Есть наслаждение и в дикости лесов»- «Есть наслаждение и в сумраке лесов», а вместо «Для сердца ты всего дороже» - «Для сердца моего дороже» (курсив мой. - В. К.) [Пушкин, 1949: 428]. Эти варианты не восходили к первоначальному тексту Батюшкова-Блудова и тоже ориентированы на описанную редактуру.

А поскольку пушкинская копия не могла появиться раньше 1827 г., когда Пушкин готовил текст к публикации, то «зачем Пушкину понадобилось записывать элегию в принадлежащую ему книгу Батюшкова, когда у него либо уже был, либо вот-вот должен был появиться экземпляр “Северных цветов" с ее публикацией, которую он сам же и готовил? С какой целью 
и для кого была сделана эта запись?» [Балакин: 18]. Исследователь «подверстывает» этот текст к изданию 1834 г.: Пушкинде намеревался еще «улучшить» ранее отредактированную элегию Батюшкова. Но - совсем не очевидно, что этот, уточненный вариант был бы «лучше». Он вполне мог быть, например, ранним вариантом той редакции, которая появилась в наборной рукописи.

Нам представляется, что Пушкин внес в экземпляр «Опытов...» эту последнюю элегию Батюшкова как единственный пример состоявшегося редактирования «недоработанного» батюшковского текста, в результате которого получилось художественно совершенное творение «школы гармонической точности», образеи, на который можно было ориентироваться при проведении подобных операций применительно к остальным текстам, вошедшим в поэтический сборник. Вписана эта элегия в экземпляр «Опытов...» была, без сомнения, не ранее 1827 г. - когда «редакторская» работа Пушкина была завершена.

На эту, несостоявшуюся, попытку редактирования «Опытов в стихах», несомненно, наложило отпечаток то душевное состояние, в котором после 1821 г. находился Батюшков.

\section{«Не дай мне Бог сойти с ума...»}

Как предположил академик М. П. Алексеев, стихотворение Пушкина «Не дай мне Бог сойти с ума...» написано под впечатлением последней встречи с больным Батюшковым. Встреча эта состоялась в Москве, в маленьком домике в Грузинах, куда Батюшков, после пяти лет неудачного лечения в германской клинике, был привезен вместе с наблюдавшим его доктором Антоном Дитрихом. Сохранился любопытный дневник доктора. В феврале 1830 г. поэт заболел воспалением легких и Дитрих решил, что он умирает. Слух об этом разнесся по литературной Москве - и многие давние знакомые Батюшкова поспешили проститься с ним. 22 марта была отслужена всенощная, во время которой поэт «лежал неподвижно на диване с закрытыми глазами». И далее: «Поэт Александр Пушкин, бывший во время службы вместе с Муравьевой и княгиней Вяземской, подошел к столу, у которого лежал 
больной, и, отстранив свечу, с оживлением начал говорить что-то больному, который не шевельнулся и не промолвил ни слова, даже не обратил внимания на лиц, стоявших у него в прихожей. Вероятно, ему слышалось пение архангелов» [Алексеев: 370].

Завершив - в начале 1820-х гг. - свой кропотливый труд по редактированию поэтического сборника Батюшкова, Пушкин оказался в двусмысленной ситуации.

Если бы автор сборника — как и планировалось вначале вернулся из своих итальянских странствий, то неизбежно состоялись бы встречи, обсуждения, обмен мнениями; Пушкин высказал бы Батюшкову свои сомнения и наблюдения и - так или иначе - побудил бы того к продолжению поэтических поисков.

Если бы автор умер, то в этом случае его друзья получали «почти посмертное разрешение» [Вацуро: 160] исправлять в его стихах «ошибки против смысла и языка»: «Правь сам и всем давай исправлять» [Батюшков: 435].

Но Батюшков остановился «на полдороге» - и «умер» только «для поэзии». В этом случае «посмертное разрешение» уже, что называется, не работало.

Сложившаяся в первое десятилетие XIX в. «арзамасская» практика литературного редактирования «образцовых» сочинений прошлых лет предполагала прежде всего заботу об их «улучшении» и приближении к современному читателю. С такой установкой подошли, например, Батюшков и Жуковский к подготовке посмертного издания сочинений М. Н. Муравьева, в котором основную трудность вызвала как раз стихотворная часть. По первоначальному замыслу стихотворения должны были составить отдельный том, но в конечном счете в «Полном собрании сочинений» Муравьева (1818-1820) стихотворения составили лишь начало первого тома.

В основу был положен список, наполненный многочисленными ошибками переписчика. «Из 44 стихотворений Жуковский отобрал 24 и добавил 2 из журналов». И в состав собрания Муравьева «вошло всего 26 стихотворений (главным образом ранних) - незначительная часть его поэтического наследия» [Кулакова: 321]. Осуществив таким образом необходимое 
«очищение» поэтического наследия предшественника, Батюшков и Жуковский активно «улучшали» представленный в печати текст: сокращали длинноты, «редактировали» неудачные выражения и т. д., руководствуясь, в основном, вкусовыми критериями. Пушкин, в сущности, решал такую же задачу с наследием Батюшкова.

Пушкинское редактирование было прямым наследием этой «арзамасской» практики и тоже являлось произвольным. Показательный пример - помета возле элегии «Мой гений»: «Прелесть, кроме первых 4 <стихов>» [Пушкин, 1949: 262]. Эти «отвергнутые» первые стихи, между тем, приобрели особенную популярность и стали в массовом сознании едва ли не знаменем всего творчества Батюшкова:

О память сердца! ты сильней

Рассудка памяти печальной,

И часто сладостью своей

Меня в стране пленяешь дальной.

Дальнейшее описание возлюбленной, обращение к ней и к жизненному «хранителю-гению» может быть воспринято и без этого начального восклицания. Но при этом оно лишается того, что Батюшков называл своей «маленькой философией» и что руководило многими его чувствами и поступками. Пушкин, в начале творческого пути далекий от подобной философии (воспринятой, впрочем, от французских просветителей), не уловил глубины поэтического высказывания поэта-предшественника и, если бы его "редактирование» стихов Батюшкова реализовалось в конкретном издании, мог бы запросто выбросить эти четыре стиха, полагая, что «прелесть» стихотворения от этого только увеличится.

Подобного рода «парадоксы» представляла тогдашняя практика редактирования, которая только еще подходила к осознанию отношения к тексту как к «памятнику» чужой поэтической личности. Для Пушкина это осознание оказалось напрямую связано с «нереализованной» правкой стихов Батюшкова: поэт, оставивший поэтическое творчество, оставался жить физически - и вполне мог «вернуться» к прежнему состоянию. Именно это ощущение хрупкости творческого бытия - по сути трагическое - заставляло Пушкина время от времени возвращаться к тому экземпляру «Опытов в стихах», 
который он еще в начале творческого пути так активно проработал.

Описанная выше полемика о пометах Пушкина на полях «Опытов в стихах» Батюшкова опиралась прежде всего на пушкинскую творческую биографию и прагматику - и обнаружила большой разброс мнений в датировке, смысле и толковании одних и тех же замечаний. Нам представляется, что при изучении этих необычных маргиналий недостаточно исходить только из пушкинской прагматики - необходимо иметь в виду и «вторую сторону». В пометах на «Опытах в стихах» зримо присутствует то целеполагание, которое связано с личностью и судьбой автора книги, большого и «истинного» поэта Батюшкова, с которым Пушкин вступал в активный диалог.

Учет этого «фактора Батюшкова» приводит к следующим выводам:

1. В большинстве своем маргиналии Пушкина на полях книги Батюшкова - это пометы не полемического, а редакторского характера. Они были вызваны соответствующей просьбой «старшего поэта» и свидетельствуют, по всей видимости, о многократном обращении Пушкинаредактора к тому «Опытов в стихах», начиная с 1818 г. и вплоть до получения известия о душевном заболевании Батюшкова в 1822 г.

2. Цель обращения Батюшкова к «чуткому уху» молодого Пушкина была связана с желанием «предпринять другое издание» собственных стихов и исправить ошибки, допущенные в первом издании: убрать плохие тексты («дрянь»), стилистически уточнить и тематически заострить «заветные» произведения. Пушкин, получив это конкретное «задание», отнесся к нему со всей ответственностью и предложил автору советы по радикальной правке его стихов.

3. Столкнувшись с невозможностью довести эту «правку» до адресата, Пушкин продолжил время от времени обращаться к тому же экземпляру «Опытов...», внося в него те или иные пометы (уже «для себя»). Следы подобных обращений связаны с подготовкой собственного (первого) сборника лирических произведений Пушкина в начале 1825 г. или с открывшейся возможностью представить «отредактированную» последнюю элегию Батюшкова в конце 1827 г. - единственный пример «реализованной» пушкинской правки. Несомненно, Пушкин обращался 
к этому «диалогу» и позднее: приведенные выше наблюдения ученых, датирующих его пометы 1833-1834 гг. (см.:

[Семенко], [Балакин]), отнюдь не безосновательны.

Проблема датировки изучаемых помет в свете подобной «прагматики» представляется нам второстепенной: маргинальные замечания Пушкина отразили его многократные обращения к произведениям Батюшкова, предпринятые с самыми разными целями и возможные на любом из этапов его стремительной творческой эволюции.

\section{Примечания}

1 В этом издании пометы Пушкина были напечатаны в составе отрывка из статьи Майкова с сохранением комментариев последнего.

2 См. письмо А. И. Тургенева к П. А. Вяземскому от 20 ноября 1818 г. в: Остафьевский Архив князей Вяземских. Изд. Гр. Шереметьева. СПб.: Тип. М. М. Стасюлевича, 1899. Т. 1: Переписка князя П. А. Вяземского с А. И. Тургеневым. 1812-1819. С. 130.

3 Пантеон русской поэзии, издаваемый Павлом Никольским: в 6 ч. СПб., 1814-1815. Ч. 6. С. 234-237 (заглавие «К другу»).

4 Экземпляр стихотворного тома «Опытов...» с правкой Батюшкова воспроизведен нами в изд.: Батюшков К. Н. Сочинения. Архангельск: Северо-Западное кн. изд-во, 1979.

\section{Список литературы}

1. Абрамович С. Пушкин в 1833 году: Хроника. - М.: Слово / Slovo, 1994. - $618 \mathrm{c}$.

2. Алексеев М. П. Несколько новых данных о Пушкине и Батюшкове // Известия АН СССР. Отд. лит. и языка. - 1949. - Т. VIII. - Вып. 4. C. 369-372.

3. Балакин А. Ю. Еще о прагматике и датировке пушкинских помет на второй части «Опытов в стихах и прозе» К. Н. Батюшкова // Slavica Revalensia. - 2016. — № 3. - Pp. 9-28 [Электронный ресурс]. - URL: http://publications.tlu.ee/index.php/slavica/article/view/521/409 (05.06.2018).

4. Батюшков К. Н. Сочинения: в 2 т. / сост., подгот. текста, коммент. В. А. Кошелева, А. Л. Зорина. - М.: Худож. лит., 1989. - Т. 2: Из записных книжек. Письма. -719 с.

5. Вацуро В. Э. Последняя элегия Батюшкова // Вацуро В. Э. Записки комментатора. - СПб.: Академический проект, 1994. - С. 150-166.

6. Вяземский П. А. Записные книжки (1813-1848) / изд. подгот. В. С. Нечаева. - М.: Наука, 1963. - 507 с.

7. Вяземский П. А. Письма к К. Н. Батюшкову (публ. В. А. Кошелева) // Литературный архив: Материалы по истории русской литературы и общественной мысли. - СПб.: Наука, 1994. - С. 118-143. 
8. Гинзбург Л. Я. О лирике. - 2-е изд., доп. - Л.: Худож. лит., 1974. - 408 с.

9. Горохова Р. М. Пушкин и элегия К. Н. Батюшкова «Умирающий Тасс» (К вопросу о заметках Пушкина на полях «Опытов» Батюшкова) // Временник Пушкинской комиссии. 1976. - Л.: Наука, 1979. - С. 24-45.

10. Дмитриев М. Мелочи из запаса моей памяти. - 2-е изд., доп. - M.: Изд-е Русского Архива; Тип. Грачева и Комп., 1869. — 297 с.

11. Зубков Н. Н. Опыты на пути к славе: О единственном прижизненном издании К. Н. Батюшкова // Зорин А. Л., Зубков Н. Н., Немзер А. С. Свой подвиг свершив: О судьбе произведений Г. Р. Державина, К. Н. Батюшкова, В. А. Жуковского. - М.: Книга, 1987. - С. 263-348.

12. Кац Б. А. «Звуки италианские!» // Временник Пушкинской комиссии. 1981. - Л.: Наука, 1985. - С. 168-171.

13. Комарович В. Л. Пометки Пушкина в «Опытах» Батюшкова // [Александр Пушкин]. - М.: Журнально-газетное объединение, 1934. - С. 885-904. (Литературное наследство; Т. 16/18).

14. Кошелев В. А. Пушкин и «пастор Ганнеман» // Временник Пушкинской комиссии. - Л.: Наука, 1988. - Вып. 22. - С. 167-168.

15. Кошелев В. А. В предчувствии Пушкина: К. Н. Батюшков в русской словесности начала XIX века. - Псков: Изд-во Псков. обл. ин-та усовершенствования учителей, 1995. - 122 c.

16. Кошелев В.А.Константин Батюшков: Феномен «домашней» критики // Очерки по истории русской литературной критики: в 4 т. - СПб.: Наука, 1999. - Т. 1: XVIII - первая четверть XIX в. - С. 221-246.

17. Кошелев В. А. О феномене намеренной дубиальности // Tusculum Slavicum: Festschrift für Peter Thiergen. — Zürich: Pano, 2005. - S. 87-95 [Электронный ресурс]. — URL: http://lib.pushkinskijdom.ru/LinkClick. aspx?fileticket=YIxYzn4D7DE\%3D\&tabid=10358 (05.06.2018).

18. Кулакова Л. И. Примечания // Муравьев М. Н. Стихотворения. - Л.: Сов. писатель, 1967. - С. 319-360.

19. Летопись жизни и творчества Александра Пушкина: в 4 т. / сост. М. А. Цявловский, Н. А. Тархова. - М.: Слово / Slovo, 1999. - Т. 1: 1799-1824. - 592 c.

20. Лотман Ю. М. Историко-литературные заметки // Труды по русской и славянской филологии. - Тарту, 1960. - Вып. III. - С. 311-312.

21. Майков Л. Н. Пушкин о Батюшкове // Майков Л. Пушкин. Биографические материалы и историко-литературные очерки. - СПб.: Л. Ф. Пантелеев, 1899. - С. 284-317.

22. Модзалевский Б. Л. Библиотека А. С. Пушкина (Библиографическое описание). Отдельный оттиск из издания «Пушкин и его современники», вып. IX-X. - СПб.: Тип. Императорской Академии наук, 1910. - 441 с.

23. Плетнев П. А. Письмо к графине С. И. С. о русских поэтах // Северные цветы на 1825 год, собранные бароном Дельвигом. - СПб., 1824. C. $3-80$.

24. Проскурин О. А. Литературные скандалы пушкинской эпохи. - М.: ОГИ, 2000. -368 с. 
25. Проскурин О. А. Пометы Пушкина на полях «Опытов в стихах» Батюшкова: датировка, функция, роль в литературной эволюции // Новое литературное обозрение. - 2003. - № 64 (6). - С. 251-283.

26. Пушкин А. С. <Сочинения>: в 6 т. / под ред. С. А. Венгерова. - СПб.: Брокгауз-Ефрон, 1910. - T. IV. - [2], 560, LXXX c.

27. Пушкин А. С. Полн. собр. соч.: в 16 т. - М.; Л.: Изд-во АН СССР, 1937. - Т. 13. Переписка. 1815-1827. - 651 с.

28. Пушкин А. С. Полн. собр. соч.: в 16 т. - М.; Л.: Изд-во АН СССР, 1949. - Т. 12. Критика. Автобиография. - 576 с.

29. Рукою Пушкина: Несобранные и неопубликованные тексты / подгот. к печати и коммент. М. А. Цявловский, Л. Б. Модзалевский, Т. Г. Зенгер. - М.; Л.: Academia, 1935. - 926 c.

30. Сандомирская В. Б. К вопросу о датировке помет Пушкина на второй части «Опытов» Батюшкова // Временник Пушкинской комиссии. 1972. - Л.: Наука, 1974. - Вып. 10. - С. 16-35.

31. Семенко И. М. Батюшков и его «Опыты» // Батюшков К. Н. Опыты в стихах и прозе. - М.: Наука, 1977. - С. 433-492 (Литературные памятники).

Информация об авторе: Кочелев Вячеслав Анатольевич - доктор филологических наук, профессор, действительный член Международной и Российской академии наук высшей школы, ведущий специалист Центра менеджмента научно-исследовательской работы Арзамасского филиала Нижегородского государственного университета им. Н. И. Лобачевского.

Дата поступления в редакиию: 30.06.2018 Дата публикащии: 01.10.2018

Vyacheslav A. Koshelev (Arzamas, Nizhny Novgorod region, Russian Federation) viacheslav.koshelev@mail.ru

\section{About One Old "Paradox": the Genre of Marginalia by A. S. Pushkin Based on "Experiments in Verse and Prose " by K. N. Batyushkov}

Abstract. In the center of the article there are famous Russian literary marginalia: notes made by of A. S. Pushkin in the margins of the poetic volume "Experiments in Verse and Prose" by K. N. Batyushkov and the academic dispute dedicated to them. The author offers a series of arguments to prove that Pushkin's marks were not polemic, but editorial in nature. They were made in 1818 due to the request of Batyushkov himself and were an attempt of a "younger" poet to accomplish a "critical task" of his predecessor. The margin notes give evidence of a persistent and repeated appeal of Pushkin to the book of Batyushkov. This "frequency" set up the problem of remarks dating: different researchers, making different 
interpretations of Pushkin's statements, refer them to the end of 1810 s, or 1820 s, or the middle of the $1830 \mathrm{~s}$. The author proves the need to take into consideration first of all the target of the margin notes and their history: in the light of bilateral "pragmatics" the problem of dating the marks takes a back seat.

Keywords: K. N. Batyushkov, "Experiments in Verse and Prose", A. S. Pushkin, notes in the margins, genre of marginalia, copy editor, criticism, polemics, dating, interpretation

\section{References}

1. Abramovich S. Pushkin v 1833 godu: Khronika [Pushkin in 1833: The Chronicle]. Moscow, Slovo Publ., 1994. 618 p. (In Russ.)

2. Alekseev M. P. A Some More Data on Pushkin and Batyushkov. In: Izvestiya Akademii nauk SSSR. Otdelenie literatury $i$ yazyka [Bulletin of the Russian Academy of Sciences: Studies in Language and Literature], 1949, vol. 8, issue 4, pp. 369-372. (In Russ.)

3. Balakin A. Yu. More About Pragmatics and Dating of Pushkin's Notes on the Margins of the Second Part of "Experiments in Poetry and Prose" by K. N. Batyushkov. In: Slavica Revalensia, 2016, no. 3, pp. 9-28. Available at: http://publications.tlu.ee/index.php/slavica/article/view/521/409 (accessed on June 05, 2018). (In Russ.)

4. Batyushkov K. N. Sochineniya: $v 2$ tomakh [Writings: in 2 Vols]. Moscow, Khudozhestvennaya literatura Publ., 1989, vol. 2: From Notebooks. Letters. 719 p. (In Russ.)

5. Vatsuro V. E. The Last Elegy of Batyushkov. In: Vatsuro V. E. Zapiski kommentatora [Vatsuro V. E. The Notes of Commentator]. St. Petersburg, Akademicheskiy proekt Publ., 1994, pp. 150-166. (In Russ.)

6. Vyazemskiy P. A. Zapisnye knizhki (1813-1848) [Notebooks (1813-1848)]. Moscow, Nauka Publ., 1963. 507 p. (In Russ.)

7. Vyazemskiy P. A. Letters to K. N. Batyushkov (Publication of V. A. Koshelev). In: Literaturnyy arkhiv: Materialy po istorii russkoy literatury i obshchestvennoy mysli [Literary Archive. Materials on the History of Russian Literature and Social Thought]. St. Petersburg, Nauka Publ., 1994, pp. 118-143. (In Russ.)

8. Ginzburg L. Ya. O lirike [About the Lyrics]. Leningrad, Khudozhestvennaya literatura Publ., 1974. 408 p. (In Russ.)

9. Gorokhova R. M. Pushkin and the Elegy of K. N. Batyushkov "Dying Tass" (More on Pushkin's Margin Notes in "Experiments" by Batyushkov). In: Vremennik Pushkinskoy komissii. 1976 [The Chronicle of the Pushkin Committee. 1976]. Leningrad, Nauka Publ., 1979, pp. 24-45. (In Russ.)

10. Dmitriev M. Melochi iz zapasa moey pamyati [Little Things From the Stock of My Memory]. Moscow, Izdanie Russkogo Arkhiva Publ., Tipografiya Gracheva i Ko Publ., 1869. 297 p. (In Russ.)

11. Zubkov N. N. Experience on the Way to Glory: About the Only Intravital Edition of K. N. Batyushkov's Book. In: Zorin A. L., Zubkov N. N., Nemzer A. S. Svoy podvig svershiv: O sud'be proizvedeniy G. R. Derzhavina, K. N. Batyushkova, V. A. Zhukovskogo [Zorin A. L., Zubkov N. N., Nemzer A. S. Having Accomplished 
One's Feat: About the Destiny of the Works of Derzhavin, K. N. Batyushkov, V. A. Zhukovsky]. Moscow, Kniga Publ., 1987, pp. 263-348. (In Russ.)

12. Kats B. A. "Italian Sounds!" In: Vremennik Pushkinskoy komissii. 1981 [The Chronicle of the Pushkin Committee. 1981]. Leningrad, Nauka Publ., 1985, pp. 168-171. (In Russ.)

13. Komarovich V. L. Margin Notes of Pushkin in the "Experiments" by Batyushkov. In: Alexander Pushkin. Moscow, Zhurnal'no-gazetnoe ob"edinenie Publ., 1934, pp. 885-904. ("Literary Heritage”; vol. 16/18). (In Russ.)

14. Koshelev V. A. Pushkin and "Pastor Hanneman". In: Vremennik Pushkinskoy komissii [The Chronicle of the Pushkin Committee]. Leningrad, Nauka Publ., 1988, issue 22, pp. 167-168. (In Russ.)

15. Koshelev V. A. V predchuvstvii Pushkina: K. N. Batyushkov v russkoy slovesnosti nachala 19 veka [In Anticipation of Pushkin: K. N. Batyushkov in the Russian Literature of the Early 19th Century]. Pskov, Pskov Regional Teachers-inService Institute Publ., 1995. 122 p. (In Russ.)

16. Koshelev V. A. Konstantin Batyushkov: The Phenomenon of "Home" Criticism. In: Ocherki po istorii russkoy literaturnoy kritiki: $v 4$ tomakh [Essays on the History of Russian Literary Criticism: in 4 Vols]. St. Petersburg, Nauka Publ., 1999, vol. 1: The 18th - First Quarter of the 19th Century, pp. 221-246. (In Russ.)

17. Koshelev V. A. On the Phenomenon of Variability of Authorship. In: Tusculum Slavicum: Festschrift für Peter Thiergen. Zürich, Pano Publ., pp. 87-95. Available at: http://lib.pushkinskijdom.ru/LinkClick.aspx?fileticket=YIxYzn4D7DE\%3D\&tabid=10358 (accessed on June 5, 2018). (In Russ.)

18. Kulakova L. I. Notes. In: Murav'ev M. N. Stikhotvoreniya [Muravyov M. N. Verses]. Leningrad, Sovetskiy pisatel' Publ., 1967, pp. 319-360. (In Russ.)

19. Letopis'zhizni i tvorchestva Aleksandra Pushkina: $v 4$ tomakh [The Chronicle of Life and Work of Alexander Pushkin: in 4 Vols]. Moscow, Slovo Publ., 1999, vol. 1: 1799-1824. 592 p. (In Russ.)

20. Lotman Yu. M. Historical and Literary Notes. In: Trudy po russkoy $i$ slavyanskoy filologii [Works on Russian and Slavic Philology]. Tartu, 1960, issue 3, pp. 311-312. (In Russ.)

21. Maykov L. N. Pushkin About Batyushkov. In: Maykov L. Pushkin. Biograficheskie materialy i istoriko-literaturnye ocherki [Maykov L. N. Pushkin. Biographical Materials and Historical and Literary Essays]. St. Petersburg, L. F. Panteleev Publ., 1899, pp. 284-317. (In Russ.)

22. Modzalevskiy B. L. Biblioteka A. S. Pushkina (Bibliograficheskoe opisanie). Otdel'nyy ottisk iz izdaniya "Pushkin i ego sovremenniki» [A. Pushkin's Library (Bibliographic Description). A Separate Print from the Issue "Pushkin and His Contemporaries”]. St. Petersburg, Tipografiya Imperatorskoy Akademii Nauk Publ., 1910, issue 9-10. 441 p. (In Russ.)

23. Pletnev P. A. A Letter to Countess S. I. S. About Russian Poets. In: Severnye tsvety na 1825 god, sobrannye baronom Del'vigom [Northern Flowers of 1825, Collected by Baron Delvig]. St. Petersburg, 1824, pp. 3-80. (In Russ.)

24. Proskurin O. A. Literaturnye skandaly pushkinskoy epokhi [Literary Scandals of the Pushkin Era]. Moscow, Ob"edinennoe gumanitarnoe izdatel'stvo Publ., 2000. 368 p. (In Russ.) 
25. Proskurin O. A. Pushkin's Marks on the Margins of the "Experiences in Verses" of Batyushkov: Dating, Function, Role in Literary Evolution. In: Novoe literaturnoe obozrenie [New Literary Observer], 2003, no. 64 (6), pp. 251-283. (In Russ.)

26. Pushkin A. S. Sochineniya: $v 6$ tomakh [Writings: in 6 Vols]. St. Petersburg, Brokgauz-Efron Publ., 1910, vol. 4. 560 p. (In Russ.)

27. Pushkin A. S. Polnoe sobranie sochineniy: $v 16$ tomakh [The Complete Works: in 16 Vols]. Moscow, Leningrad, Academy of Sciences of the USSR Publ., 1937, vol. 13: Correspondence. 1815-1827. 651 p. (In Russ.)

28. Pushkin A. S. Polnoe sobranie sochineniy: $v 16$ tomakh [The Complete Works: in 16 Vols]. Moscow, Leningrad, Academy of Sciences of the USSR Publ., 1949, vol. 12: Criticism. Autobiography. 576 p. (In Russ.)

29. Rukoyu Pushkina: Nesobrannye i neopublikovannye teksty [Pushkin's Handwriting: Uncollected and Unpublished Texts]. Moscow, Leningrad, Academia Publ., 1935. 926 p. (In Russ.)

30. Sandomirskaya V. B. On the Question of the Dating of Pushkin's Marks in the Second Part of Batyushkov's "Experiments". In: Vremennik Pushkinskoy komissii. 1972 [The Chronicle of the Pushkin Committee. 1972]. Leningrad, Nauka Publ., 1974, issue 10, pp. 16-35. (In Russ.)

31. Semenko I. M. Batyushkov and His "Experiments". In: Batyushkov K. N. Opyty v stikhakh i proze [Batyushkov K. N. Experiments in Verse and Prose]. Moscow, Nauka Publ., 1977, pp. 433-492. (In Russ.)

Information about the author: Koshelev Vyacheslav A. Doctor of Philology, Professor, Full Member of the Russian and International Academy of Sciences, Leading Specialist of the Management Center of Scientific Research Work of Lobachevsky State University of Nizhny Novgorod (The Arzamas Branch).

Received: June 30, 2018

Date of publication: October 1, 2018 